almost ideal laboratory method of studying such effects. They joined him to form the Strangeways team for an attack on these problems. A programme of radiological research extending over a number of years was drawn up which, with some modifications, is still being pursued by several of the members of the Strangeways Research Laboratory.

The programme included the investigation of the earliest observable effects of irradiation; immediate and delayed lesions and lethal action; growth stimulation and retardation; vulnerability in relation to the various phases of the life-cycle; relative efficiencies of intermittent and continued irradiation ; variation in response due to changes of quality and intensity; and the separation of direct from indirect actions. Canti's genius showed itself in the many new instruments, appliances and techniques which he evolved to elucidate these problems and in the valuable results obtained by him and his collaborators which are published in numerous papers in various radiological and biological journals. Special reference must be made to the now world-famous cinema photomicrographic study which he made on the effects of gamma rays on normal and malignant cells grown in vitro. The first apparatus used by Canti for this purpose was constructed from Meccano parts and erected by him in his private house. With it he secured the superb photomicrographs which are now shown in all the continents of the world, and have probably been the means of convincing more people of the efficacy of the radiation treatment of cancer than any other form of publication. For this work Canti received the Röntgen award of the British Institute of Radiology and shared with other members of the Strangeways Research Laboratory the Garton prize of the British Empire Cancer Campaign.

At the time of his death Canti was honorary secretary to the Scientific Advisory Committee of the British Empire Cancer Campaign, to the Cancer Research Committee of St. Bartholomew's Hospital, and scientific adviser to the British Red Cross Blood Transfusion Service. His distinguished appearance, his modesty and great personal charm impressed everyone with whom he came in contact. His loss will be deeply felt by a very wide circle.

In 1912 Canti married Clare Eyles, who nursed him through his last long illness which terminated in pneumonia. He leaves four children, of whom the youngest son is at present a student at St. Bartholomow's Hospital.

F. L. H.

\section{Dr. Herbert Bolton}

Dr. Herbert Bolton, director of the Bristol Museum and Art Gallery from 1898 until 1930, died on January 18 at Reading, whence he retired in 1931. Dr. Bolton was born at Bacup, Lancashire, in 1863 and started life as a boy in the mills. He applied himself to the rigid discipline of self-education through the medium of the oldfashioned night schools, and eventually proceeded to the Royal College of Science, South Kensington, where he was a fellow student with $H$. G. Wells and Morley Davies. He afterwards went to Owens
College, Manchester, and in 1890 was appointed to an assistant keepership in the Manchester Museum.

During this period, Bolton pursued several lines of geological research, but even in these early days he was chiefly attracted by the stratigraphy and palæontology of the Coal Measures. His most important contributions to science at this stage include the publication in 1898 of a critical survey of the nomenclature of the seams in the Lower Coal Measures of Lancashire, and the palæontology of the Manx Slates, Isle of Man, in 1899. He was elected a fellow of the Royal Society of Edinburgh in 1894.

Dr. Bolton's real life-work and interest began when he was appointed curator of the Bristol Museum in 1898. He became the first director of the Museum and Art Gallery in 1911 and ably served the city of his adoption for thirty-two years. During this period the exhibition area was increased three-fold and the whole of the material was entirely recased. He always tried to visualise the visitors' point of view, and formulated many museum principles which are to-day universally accepted. Indeed many of the so-called new themes in museology expounded at the present time are to be found in his presidential address at the Wembley Conference of the Museums Association in 1924. Several of the younger generation of museum curators can testify to the intensive and extensive methods of his training. A strict disciplinarian, a ruthless but honest critic, he would first destroy the theme put forward by the budding curator and then by constructive and suggestive means gradually evolve the true solution of any museum problem. A hard and severe training it was, although many have had reason to be thankful for contact with such an inspiring and vitalising personality.

Pre-eminence in the museum world was acknowledged by Dr. Bolton's membership of the Advisory Council of the Victoria and Albert Museum in 192033 and by the invitation to give evidence before the Royal Commission on National Museums. At various times he had the opportunity and privilege of visiting the most important museums in Europe, Australia, Canada and America.

Throughout his life, Dr. Bolton always stressed the idea that curatorial work and research were complementary, and reacted both to the benefit of the curator and the institution. He put this theory into practice, and considering that throughout his time at Bristol administrative duties were continually increasing, the amount of original research that he published must be regarded as remarkable. For many years he was reader in palæontology and a member of the Court of the University of Bristol.

In 1907 and 1911 Dr. Bolton published papers on the faunal horizons in the Coal Measures of the Bristol district. In view of the fact that several of these collieries are now closed, the evidence he recorded and the specimens he collected are important. Afterwards, he became interested in several other local geological questions, but finally was inevitably drawn to the small compact group of Carboniferous insects. With Mr. J. W. Tutcher as collaborator in photography, he wrote several papers on these hitherto neglected forms. The paper in which he graphically 
described a giant dragon-fly, Boltonites [Meganeura] radstockensis, Bolton, will always have an irresistible appeal to the imagination. Eventually as a magnum opus, the Palæontographical Society published in 1921-22 a comprehensive monograph, which is now, and will probably remain for many years, the standard work of reference on this group of fossils. This work was recognised by the award of the Murchison Fund of the Geological Society of London in 1922 and the D.Sc. degree of the University of Bristol in the same year. He was elected a fellow of the Geclogical Society in 1906 and of the Zoological Society in the preceding year.

In all, Dr. Bolton published sixteen geological papers, but he will be chiefly remembered for his pioneer work in the elucidation of the Coal Measure insects. Although the genetic relationships that he suggested are admittedly tentative, they are founded on observed facts and will form the basis for future investigation on this group.

F. S. WAILIS.

Prof. William Brair-Bell, whose death on January 25 at the age of sixty-four years has been announced, held a high place among modern British physicians. $\mathrm{He}$ combined experimental methods of research with clinical observation, and did much to elucidate the control which the pituitary and other glands of internal secretion exert on the ovaries and uterus. He was gynæcologist and obstetrician to the Royal Infirmary, Liverpool, and held the chair relating to those subjects in the University of Liver. pool. In the later phase of his professional life, he sought to arrest the growth of malignant tumours by injection of a colloidal salt of lead into the veins of patients, but his results did not inspire others to adopt this mode of treatment. His best-known books are "The Sex Complex" (1916), "The Pituitary" (1919), "Some Aspects of the Cancer Problem" (1930), and "Principles of Gynæcology" (fourth edition, 1933). He received honorary degrees from the Universities of Glasgow and of Liverpool, and was elected an honorary fellow of the American College of Surgeons.

WE regret to announce the following deaths :

Sir Charles Ballance, K.C.M.G., C.B., M.V.O., formerly president of the Medical Society of London, on February 8, aged seventy-nine years.

Prof. K. C. Browning, professor of chemistry in the Military College of Science, Woolwich, on January 25, aged sixty years.

Mrs. M. French Sheldon, who made a remarkable journey from Mombasa to Mount Kilimanjaro in 1890-91 and explored the curious crater lake Chala at the south-east foot of the mountain, on February 10 , aged eighty-eight years.

Mrs. Henry Sidgwick, principal in 1892-1910 of Newnham College, Cambridge, and president in 1915 of Section L (Educational Science) of the British Association, on February 10, aged ninety years.

\section{News and Views}

\section{State Control of the Chemical Industry}

EvIDENCE relating to the State control of chemical industry and its bearing on the armaments traffic and its control was submitted to the Royal Commission on the Manufacture of and Trading in Arms at the Middlesex Guildhall on February 5-6. In a written statement of evidence which covered the whole range of its enterprise from the manufacture of explosives to fertilisers, dyes, paints and lightning fasteners, Imperial Chemical Industries, Ltd., denied that it is in any way party to any "International Armaments Ring". Military products formed only 1.8 per cent of total sales during the last five years and only 0.9 per cent of foreign sales. While not engaged in the manufacture of military products to any extent, its plant, designed for commercial products, can readily be converted to other uses should it ever become necessary. Nitric acid, which is produced in considerable quantities, is a raw material for practically all high explosives, and by-products from the hydrogenation of coal could afford intermediates used in the manufacture of high explosives. The manufacture of nitrocellulose for industrial purposes could easily be switched over to manufacture for high explosives.
The statement by I.C.I. stressed the necessity of a well-organised chemical industry in any highly industrialised country, and particularly in one with great textile industries. The trained personnel of the dyestuffs industry and its varied and flexible plant is a definite national asset, and is not directed towards the production of mustard gas or other poison gas. The large staff of organic chemists available might be expected to make contributions in the develop. ment of pharmaceutical products comparable with those of German chemists in this field. In relation to chlorine, the statement pointed out that chlorine in the form of bleaching powder, etc., is one of the most useful and important servants of the community, and provides the only efficient means of decontamins. tion after a mustard gas attack. In a personal state. ment, Sir Harry MeGowan urged that nationalisation proposals are economically unsound, and suggested the establishment of a permanent supervisory body which would with due financial safeguards co-ordinate private manufacture and provide the auxiliary help neessary when the demand is in excess of the capacity of private concerns. This body would be a shadow of the Ministry of Munitions; but should be appointed by the industry itself. 